Research article

\title{
A conversation about the state in pandemic times
}

\section{Necropolitics and the legacy of social democracy in Sweden and Nicaragua}

\author{
Linda Berg and Erika Alm
}

Established ideas about state responsibility and state violence are placed in a new light in times characterized as states of emergency. The following conversation addresses the role of the state in the safeguarding of public health, taking its departure in media debates and political debates about state responsibility in two countries that have been criticized for not taking strong enough measures to protect the very futuriority of the nation in times of a pandemic Sweden and Nicaragua. Both countries have been castigated for avoiding total lockdown and for having taken a passive approach to what Wendy Brown has called "the political management of the virus" (Brown 2020). At the same time, the rhetoric used to describe their respective strategies has differed vastly in dialogue we explore notions about governance, biopolitics and necropolitics as they are articulated and negotiated in national contexts that claim the label social democracies. One of the points of departure is that while the response to Covid-19 is often described in war metaphors, and hence as a state of emergency, the unjust and unequal distribution of life and death is by no means exceptional.

Keywords: Virus management; Necropolitics; Social democracy; Nicaragua; Sweden

Det följande är ett samtal om statens roll i värnandet om folkhälsan, som tar sin utgångspunkt i de mediedebatter och politiska debatter om statligt ansvar som utspelat sig i två länder som har kritiserats för att inte ha vidtagit tillräckligt kraftfulla åtgärder för att skydda själva nationens framtid: Sverige och Nicaragua. Bägge länder har kritiserats för att ha undvikit total lockdown och för att ha intagit en passiv position i det Wendy Brown har kallat för "den politiska hanteringen av viruset" (Brown 2020), men retoriken som använts för att karaktärisera deras respektive strategier har varit väsensskild. I dialog utforskar vi frågor om styrning, biopolitik och nekropolitik såsom de artikuleras och förhandlas i nationella kontexter som kallar sig socialdemokratier. En av utgångspunkterna är att medan hanteringen av Covid-19 ofta beskrivs i krigsmetaforer, och därmed som ett undantagstillstånd, så är den orättvisa och ojämlika fördelningen av liv och död som vi ser i pandemins kölvatten inte på något sätt exceptionell.

Nyckelord: Virushantering; Nekropolitik; Socialdemokrati; Nicaragua; Sverige

A s the first wave of the Covid-19 pandemic spread around the globe we were finalizing a book chapter on how state power is exercised through the governing of life and death, and reproduction, in Nicaragua and Sweden respectively (Alm \& Berg forthcoming). We heard echoes in some of the political disputes being waged at the time about the violent effects of state governance and responses to the pandemic in Nicaragua and Sweden, even if the lines of conflict and tension were different in the two cases.

The debates about the role of the state in struggles for reproductive justice and the role of the state in what is often called the "war on the virus" (Enloe 2020) are both expressions of managing life and death, and can be expressed as the tension between biopower and necropolitics (Mbembe 2003: 2011). Given our common interest in the maneuvering of life within the framework of the nation, we continued a dialogue anchored in our previous research and in conversation with some of the theorists that have been fundamental for our understanding of biopolitics as expressed in state governance. For example, in dialogue with Michel Foucault, we kept coming back to how the practice of modern nation states, and the regulation of their subjects, is done through "an explosion of numerous and diverse techniques for achieving the subjugations of bodies and the control of populations" (Foucault 1978: 140). The fact that many of the political debates 
about Covid-19 described the pandemic as a state of exception urged us to discuss how such a framing of the biopolitics of managing the pandemic overshadows the fact that the unequal and unjust distribution of life and death by no means is exceptional, but is at the core of state governance and is in some senses mundane (Enloe 2020; Hartman 2020). Here we found conversation partners in the short essays written by some of our most influential theorists of biopolitics and governance, such as Wendy Brown and Saidiya Hartman, published in the The Quarantine Files (2020). They helped us to think through the fact that current conversations about the biopolitics of managing a pandemic reflect hegemonic discourses about nation-states as sovereign for a circumscribed space and population, even in times of global interconnection (Hartman 2020; Weizman 2020).

In this conversation we also wanted to explore how Sweden and Nicaragua, both of whom claim the label of social democracy, negotiate the violent effects of state governance with their understanding of the state as a benevolent parent with a responsibility to protect as well as discipline, its citizens. More specifically, we have been interested in the expectations played out in the public debate during the Covid-19 pandemic, when both countries were criticized for not taking strong enough measures to protect the future of the nation.

We have thus undertaken a broad reading of the political debates in Sweden and in Nicaragua as they have played out during one year of the pandemic, between spring 2020 and spring 2021, in the main national newspapers (for example Dagens Nyheter and La Prensa), in national political fora (for example reports from Swedish and Nicaraguan parliament, parliamentary debates and proceedings), and in international newspapers (such as Al Jazeera, the Guardian and New York Times). With this, together with our previous research, we have continued a dialogue, the result of which is this conversation between us.

\section{So, let's start the dialogue.}

EA: When reading the newspapers and following the debates regarding the handling of the pandemic, we were struck not only by the multitude of voices that demanded that the Swedish and Nicaraguan governments needed to take responsibility for all vulnerable citizens, but also by the wide range of interpretations of what such a call for accountability would entail. After years of research among marginalized groups in Sweden and Nicaragua, most of them vulnerable to violence and neglect, due to not conforming to norms on sex, gender and sexuality, we recognized the way in which presumed, and actual, vulnerability can be mobilized to argue for very different takes on state responsibility, depending on the political position of the ones raising their voices. Against this background of the Swedish and Nicaraguan contexts we also recognized the calls for a responsible state, formulated as an appeal to an excavation of the deeper meaning of the two concepts - the social and democracy - in the political composition of social democracy.

LB: This dialogue is a reflexive comparison that focuses on how state narratives surrounding these nations activate social democracy as a contested concept and, in times of neoliberalism and global capitalism, negotiate its connotations from two very different points of departure, especially with respect to the state's role regarding public health. On the one hand, Nicaragua is the second poorest country in the Western hemisphere where, without a well-developed welfare apparatus, the population is dependent on the familism of care (Franzoni et al 2010). Presently, the state is governed by the FSLN, a self-defined social democratic and Christian left party. On the other hand, Sweden, which scores above average when it comes to living standards - by some accounts it is even among the highest scoring countries (OECD 2017) - is often described as homologous with its strong welfare system and is attributed to the long reign of social democratic politics.

EA: As a historian of ideas I find it interesting how the social democratic notion of Folkhemmet - the people's home - takes its departure from the ideal that everyone contributes according to their inclinations and abilities, and that the state provides both basic and specialized care. It is complicated to make comparisons between the political processes and healthcare systems in Nicaragua and Sweden, given the vast differences in scope of state care and of state neglect and violence. Health indicators (e.g. the budget for health care, and the number of medical professionals) differ greatly between the two countries, the expenditure for health in Sweden is thirty times more than in Nicaragua (HuetePérez 2020). But rather than settle with this conclusion about the difficulties of comparing the two countries, we have been interested in how they have been compared, historically and in our own contemporaneity, due to the shared usage of the label social democracy. Sweden and Nicaragua have both been castigated for avoiding total lockdown during the pandemic and for having taken a passive approach to what Wendy Brown has called "the political management of the virus" (Brown 2020).

LB: It is indeed intriguing to pursue the relation between the two countries, for example, how the Swedish state and civil society supported the Nicaraguan socialist revolution and the efforts to rebuild their country after dictatorship, natural disasters and war. The Swedish Prime Minister Olof Palme was the first statesman to visit the country after the Sandinistas had proclaimed victory, and President Daniel Ortega has claimed to be inspired by Swedish social democratic ideas and the Swedish welfare state. Owing to this heritage (which was also a topic of my dissertation), I have been struck by how the critiques levelled at the countries have reflected representations about them. While critics of the Swedish government assumed that the state would behave according to ideals of inclusiveness, 
calculated scientific rationality (the supposed hallmark of secular nation-states) and an ethical responsiveness, those antagonistic towards the Nicaraguan government supposed that the state would act in an authoritarian way, well anchored in Catholic culture but also expected to adhere to socialist ideals.

\section{How did the initial reactions to the Covid-19 pandemic play out?}

EA: Sweden caught international public attention when it became clear that the government did not intend to deploy the type of rhetoric and particular strategies expected of them as the representative of a nation, described as a welfare state with a strong sense of responsibility towards its citizens. Adhering to a long tradition of balancing political involvement in the affairs of independent governmental agencies with a recognition that the expertise of independent public bodies to support policy, the Swedish government took a step back to allow the experts from the SPHA (Swedish Public Health Agency) run the day to day updates on the spreading of Covid-19 and to propose specific interventions designed to protect the population, and the economy, from it.

LB: As the world news focused on the spreading of the virus in the spring of 2020, the Nicaraguan Vice President Rosario Murillo organized a national march to manifest love in times of unrest. It was a march in solidarity with those affected and with gratitude that, according to the political leadership, "it had not spread in the country". It was called "Amor en Tiempos del Covid-19". Despite the World Health Organization's warnings against mass gatherings, the manifestation drew thousands of public workers and supporters to the streets. Critics defined it as "crazy" and felonious, exposing thousands of citizens to the virus (Salazar Mather et al 2020).

EA: With time, as country after country went into lockdown, a particular narrative formed, both in the rhetoric of Swedish experts and politicians, and in that of their critics. Namely, that the strategy of the Swedish government relied on the conviction that Swedish citizens would comply with the recommendations from the SPHA without the incentive of punitive regulations; that we as a collective would protect the weakest of our population. This strategy, which according to some critics also relied on the development of so-called 'herd immunity' through a slow and contained spread of the virus in the population, has not been codified in an officially formulated strategy, but rather communicated in continuous press conferences and press releases. The Swedish government and the SPHA have strongly denied that attaining herd immunity has been part of their strategy (Hallengren 2020). This has, however, been questioned by both media and scientific experts (Anderberg 2021, the Local 2021).

LB: One of the reasons why we were motivated to continue to talk about the parallelism and disruptions between the Swedish and the Nicaraguan contexts, is the fact that Nicaraguan politicians officially referred to their Swedish counterparts' strategy when legitimizing their own. On May 25, 2020, the Nicaraguan government released the White book for the Covid-19 pandemic with guidelines for the country (Libro Blanco 2020). In this report the regime declared that Nicaragua had been following "the Swedish model", stating that "all the countries of the world will have to combine defense against the coronavirus with the functioning of society, just as Nicaragua and Sweden have done from the beginning (Libro Blanco 2020: 13)." Further, the government claim that "Nicaragua and Sweden represent alternatives to lockdown in a developing country and a developed country, respectively (Libro Blanco 2020: 14)".

This report includes policy strategies to reduce the effects of Covid-19, an account of initiatives that the current regime had carried out in health care since they took power in 2007. It also describes an ongoing attack against the party, with the spread of misinformation regarding the pandemic situation in Nicaragua.

It was timely to refer to the Swedish government's approach. In a Nicaraguan context Sweden has been known as a generous nation with a history of supporting small socialist states. During the 1980s, Daniel Ortega and Olof Palme joined forces in their critique of North American imperialism, and there was between them a consensus regarding the importance of redistributing resources. Ortega and his followers still carry this image, for example in their rhetoric against "neoliberalism" and "imperialism". At the same time, the leadership has pushed through neoliberal policies: lower taxes for the rich, and not forgetting the fact that the U.S is Nicaragua's largest trading partner.

EA: There was a striking difference in how the critique against the two governments targeted their respective self-images and how these self-images have been validated or questioned in national and international contexts. In the Swedish case, two characteristics can be identified in the debate about the governing of Covid19: 1) the relative autonomy of governmental agencies in formulating guidelines and restrictions, by critics described as a blind trust in bureaucrats and a lack of political initiative and accountability in the political leadership, and 2) the reliance on soft governing techniques, by critics described as at best misguided and gullible, and at worst a cynical approach to the necropolitical effects of avoiding lockdown and other more hands on governing techniques (Goodman 2020; Orange 2020; Palm 2020).

In the discussions in Swedish and international media and parliamentary debates, it has been claimed that we are witnessing the moral decline of the Swedish state. Such critical narratives describe the government as passive, while the experts of SPHA are callous bureaucrats who neither show empathy nor assume accountability for the relatively high mortality rate among the groups that were disproportionately 
affected: elderly people, people with disabilities and marginalized ethnic groups. This type of critique had a significant impact on the self-image of a state, which for decades has described itself as having, and taking, a particular type of responsibility for its most vulnerable citizens, and of a government, which is negotiating its social democratic heritage. The Swedish self-image was turned on its head, such that now, it has been argued, state neglect has had violent, discriminatory and deadly effects. If we scrutinize the claims made by the critics of the Swedish government's way of handling the pandemic, doing so in light of those discourses that speak on the core values and the governing techniques upon which a social democratic government can claim and rely, some very interesting patterns can be detected.

LB: In the Nicaraguan case, the moral downfall has long been international news. Both the national opposition and the international community were upset by the government's neglect of the pandemic; initially there was no recognition of the spread of the infection in the country and no restrictions, such as travel bans, or quarantine rules were effected. Ortega announced that closing down the work sector could lead to an "economic pandemic", and that information in the media regarding so-called express burials was "fake news" (La Prensa 2020, Al-Jazeera 2020). Local journalists documented how officials minimized the effects of the virus by writing certificates saying that victims of Covid19 had passed away due to pneumonia or other illnesses (Herrera 2020; Wilfredo \& Salazar 2021). Medical professionals warned against the consequences of ignoring the virus as an acute health problem (Pearson et al 2020). More than 700 medical doctors criticized the government for not reacting, some were forced to quit or were fired due to their critique of the regime (Celedón Lacayo et al 2020).

The challenge for the political leadership was, and still is, to keep the population from overthrowing the government. At the time of writing there are severe restrictions on freedom of expression and demonstrations, while other signs of opposition are met with repression. Amid the imprisonment of political opponents, the 2021 election has been called a "farce" by the Human Rights Watch (Solomon 2021). I see this as a continuation and intensification of anti-democratic politics after protests against cutbacks on social security in 2018, a critique which expanded into broader complaints against the government. Protests were met with force by police and paramilitary groups, and some 320 people were killed, while thousands of others were wounded and over 600 imprisoned. Between 2018-2020 more than 100000 people had sought asylum, fleeing from political persecution and human rights abuses (UNHCR, March 2020).

So, the fact that the Vice President (also, wife to the President) initiates a manifestation "for love" in times of unrest, and that the President avoids restrictions and emphasizes the economic dimensions of the crisis - is entirely in keeping with the current political rule in Nicaragua.

\section{What can we say about state accountability and biopolitics?}

EA: If we understand this message from the Nicaraguan government about love as a call for national belonging, an interpellation of the population to gather behind the government, then I believe there is a parallel discussion taking place in Sweden, namely the extent of whether a political consensus exists about the effectiveness of the Swedish government's management of the virus, discussions that also came to focus on conflicting notions not only about the moral accountability of the government in this endeavor, but also about the Swedish model of governance, i.e. the heart of the social democratic heritage of Folkhemmet. References to how the government has failed to protect its most vulnerable citizens have been advanced by politicians from across the board, but this failure has been politically charged in quite different ways, depending on the ideological position of the opposition. There was a consensus that the elderly, especially those living in care homes, are particularly vulnerable, but the analyses of why the death rates were so high differed. From conservative quarters an emphasis was placed on the government's lack of action, both to facilitate a distribution of personal protective equipment to elderly people and those caring for them, and the failure to track and contain the virus. The Christian democrat party leader, Ebba Busch, described the situation as premeditated, that the government in "cold blood had neglected to minimize the spread of the virus" (Svensson 2021). From the left, the analysis focused on the organization of elderly care: the deregulation of the social care system has left it functioning like a market, vulnerable to competition and fluctuations in supply and demand of both economic resources and a stable workforce. In September 2020 the Left party stated that the pandemic "exposed the systemic errors that have been there long before the pandemic, in the form of a lack of coordination, personnel and [protective] materials" (Vänsterpartiet 2020). While one critique focuses on the lack of political potency and willingness to lead, the other takes its departure in a critique of the marketization and neoliberalization of the welfare state.

LB: Would you say that these political discussions, about the government in acute situations, played themselves out at a time when the heritage of a social democratic welfare state is in Sweden being negotiated?

EA: Yes, at the center of these negotiations was the so-called responsibility principle that refers to the division of responsibility of governance in times of crisis. It departs from the principle that the national, regional and municipal agencies that govern a particular area, be it elderly care, health care, or education, ought also to 
be the agencies that govern these areas in times of acute crisis. It distributes responsibility and accountability in a system that relies on local agencies to be those best equipped to interpret and implement national guidelines and recommendations. It has been described as a Swedish model, allowing for flexibility and local adaptation. However, both scholars (Asp et al 2015) and governmental reports and agencies (Riksrevisionen 2008), have pointed out that the responsibility principle might hamper the coordination of crisis management.

During the parliamentary debate on the introduction of a temporary legislation in times of pandemics (on January 8 2021), enabling the government to take executive action in times of crisis, the focus was on political responsiveness and accountability. The social minister stressed that there had been an on-going dialogue and a broad political consensus in parliament about the actions taken, and that this consensus had been vital for the impact and implementation of restrictions and recommendations. She emphasized that the government's strategy had a basis in expert knowledge supplied by governmental agencies (Riksdagsdebatt 2021). Both points were met with skepticism by the opposition in the political debate and by critical voices in media outlets. There was a broad consensus that the government's passivity had not been properly held to account. In the words of the Christian democrat MP, Acko Ankarberg Johansson: "A government needs to be able to take initiative and act during a crisis. [...] The parliament is not slow. The government is slow" (Riksdagsdebatt 2021). A MP from the Conservatives purported that the trust put in experts at the SPHA had prevented the government from developing a plan that could counter the pandemic more forcefully and preparedly (Riksdagsdebatt 2021). This analysis had been advanced early on during the pandemic, by a string of open letters to the government, authored by 22 medical experts, who argued that the government's strategy ignored scientific evidence about, for example, the pros of closing down significant parts of society (Carlsson 2020).

The 22 experts formulated a very particular kind of narrative to counter the idea that there was a consensus about the government's strategy: that dissident voices are silenced and ignored, and that this poses a threat to the freedom of speech, and fosters a problematic climate of public debate (Jansson 2020). In the process of this concern being rephrased in more general terms by other critical voices, the message has kaleidoscoped: while some argue that the government is resistant to scientific facts and has operated from a purely ideological position, unwilling to accept critique, others argue that calls for lockdowns are based in affect and not calculated measures. The social democratic government has had to negotiate the complex connotations attached to the history of Folkhemmet as a form of welfare state that was reliant on a centralized bureaucracy and a political willingness to compromise with absolute individual freedom in order to achieve changes in policy and redistribution; all in the name of the common good. The tension between, on the one hand, this mythologization of the social democratic welfare state during its heyday and, on the other, the contemporary social democrats' party program and political practice generates descriptions of the Swedish government that vacillate between the deep state with its far reaching control and repressive tactics, and the weak state that is unwilling to take action and assume accountability (there is a plethora of scholarly work on the effects of neoliberalism on the so-called Swedish model, see for example: Lindbom 2001; Bergh \& Erlingsson 2009).

LB: These notions about the specificity of the Swedish model of accountability and state responsibility are also part of a story of a secular state. This is in stark contrast to Nicaragua where rhetoric regarding responsibility for lives draws on religious discourses. An example is how Ortega and the much-reformed Sandinista Party sanctioned total criminalization of abortion, in order to guarantee the support from the churches and win the election already in 2006. The religious rhetoric reinforces the perception of a credible leadership that takes care of the whole population, which includes the fetus/ the future citizen. In practice this means that penalties for ending pregnancy - even if the result of a sexual crime - presents a risk to the life and health of the pregnant person or a risk of serious fetal impairment (Reploge 2007; Bradshaw et al 2008; Heumann 2014). Numerous women have died of complications during pregnancy and from illegal abortions etc. Bodies defined as women are marked as bodies designed for reproductive work. During the pandemic women are not just expected to take care of sick family members, they are also exploited as understaffed nurses in a downsized health care system (Kuwalchuk 2018). The consequences for impoverished women are thus brutal; forced to do reproductive work, to engage in productive work and to live in crowded households, exposed to risks and dangers to life, whether due to an illegal abortion or a virus. Here, it is inevitable to talk about necropolitics against a specific part of the population. The current pandemic situation makes it clear that life and death are state regulated events, giving us examples of how nations exercise their power over the people. In an economically weak state, led by an authoritarian regime, it becomes painfully clear how necropolitics is concerned with sovereignty whose central project is the instrumentalization of humans, including the destruction of human bodies, rather than the struggle for autonomy (Mbembe 2003).

EA: What would you say is the relation between this necropolitical praxis of state repression and neglect and the way in which the Nicaraguan government is presenting itself as responsible and accountable to the effects of the pandemic?

LB: No one denies that Nicaragua is what the government calls a "developing country", and all 
strategies are related to this fact. When Ortega critiques imperialist nations for exploiting the so-called Global South and says that Nicaraguans "haven't stopped working, because if this country stops working, it dies", his words are seen as those of a responsible and realistic leader representing a vulnerable nation (Baltodano 2020). For centuries, the world governance from Europe and North America has delivered slavery, colonialism, capitalism and patriarchy. There are reasons for rage from the so-called Global South, but for Ortega it also functions as a strategy to point at the imperial states and deny the enormous shortcomings in democratic and responsible government during the pandemic.

Political critics called the reactions to the pandemic from the Ortega-Murillo regime and the incumbent government as "surprising", even "shocking", but I am inclined to use different adjectives to understand what has happened and continues to happen. The authoritarian leadership is twisting and turning to keep power. In deploying the rhetoric of love and care, the political leaders of Nicaragua are seeking to harness the transformative potential of emotions (Ahmed 2014), strengthening feelings of a national we that will survive despite the emergency. The reference to Sweden, a social democracy in a developed country, became an excellent way of presenting good governance. It is possible to interpret the at first bizarre reaction, when mobilizing a campaign of love, as a way for the socialist identified leadership to reach highly venerated values - such as love and belonging - in times when hypercapitalism has redefined the meanings of democracy and the good life (Brown 2015). And yet, ironically, confirming neoliberal ideology through a rhetorical appeal to people as winners, e.g. the resilience of the Nicaraguan population, unlike the United States etc.

\section{No back to normal: National representations and disposable lives}

EA: Early on in the conversations we have shared over this past year we talked, in dialogue with Cynthia Enloe (2020), about the use of war metaphors in contemporary discussions about Covid-19, and how they risk sedimenting a rhetoric of exceptionalism and hence also "legitimizing state secrecy, suspending civil rights, discouraging messy public debates" (Enloe 2020). Such rhetoric, which we have found in both the Nicaraguan and Swedish contexts, can contribute to an allocation of resources that restricts and narrows the access to public health for the most vulnerable groups. Enloe points out how the right to abortion was restricted during Donald Trump's last year, with explicit reference to the need to use the means to fight Covid-19 (Enloe 2020).

LB: As Kahinde Andrews has remarked, we must remember the geopolitics in the debate regarding Covid19: the fact that millions of people die of hunger each year and that the West has become accustomed with human lives being erased on "a scale that would be unimaginable in the West" (Andrews 2020). The political leadership must also be understood in times of globalization, when politics of an economically vulnerable country, such as Nicaragua, is dependent on intergovernmental support, business relationships and not least from international financial institutions. For example, at the end of 2020, the World Bank decided to support Nicaragua (with 20 million dollars) with a Covid-19 response project for critical supplies for national hospitals. It has become inevitable for the government to adapt to the demands from international support, whether it is states, companies, or financial institutes. A salient point here is the reactions from the population (and international community) against what they perceive as Ortega's betrayal - that the social democratic rhetoric is one thing, and practical politics another - where cuts in welfare, health and healthcare arouses anger. Nicaragua, an already eroded democracy, is deteriorating and we can see within the political apparatus patterns of authoritarian leadership. In line with this, the risk of the President being heavily criticized by the citizens for declaring lockdown or for appearing as a weak leader, are more of a "threat" to the Ortega-Murillo regime than an unclear number of deaths (Pearson et al 2020).

EA: In Sweden the discussions about why the country has suffered higher mortality rates and rates of infection than its neighboring countries have highlighted a political unwillingness, on behalf of the parliament (with some exceptions), to be held accountable to the necropolitical effects of the state's governing techniques. Discussions about political accountability and responsiveness ought to address not only the question of how an individual government ought to have taken swift and effective action in an acute situation but also the question of how inequality has increased in Sweden during the past decades, and how the country now has one of the most dramatic rises in inequality between the most affluent and the poorest (Fritzell 2016; OECD 2019). When you referred to the way in which the regulation of reproductive and productive labour has had necropolitical effects on particularly vulnerable parts of the Nicaraguan population, I am reminded of my research on how the Swedish legislation on gender recognition exceptionalizes trans citizens' civil rights in ways that have necropolitical effects (Alm 2021). Given that both the right to have one's gender marker amended and access to gender affirming health care is conditional, based not on self-determination but on a medical evaluation (Alm 2021), the striving for state recognition comes at a high price (Spade 2011, Beauchamp 2019). This process of 'folding' gender variant citizens 'into the nation' (to paraphrase Puar 2007) leaves those not deemed trustworthy unprotected and underserved, with the consequences being disproportionate poor physical and mental health and high rates of suicides (Transgender Europe 2017). 
LB: By looking closer at how Sweden and Nicaragua have been debated in public media during the pandemic period, we have seen two governments faced with the task of negotiating understandings of a contested concept. Through such public reactions, ideas regarding what social democracy is become more visible. In Nicaragua we have seen an autocracy that uses the image of being a social democratic party, with a history of healthcare initiatives and a well-thought-out political strategy regarding the pandemic with support from the welfare state of Sweden. However, there is no doubt that the welfare system has never been fully developed, and state of affairs that can be traced back to a myriad of causes including colonialism, war, and natural disasters but also corruption, inadequate political organization and decades of neoliberal politics (Cruz-Feliciano 2019).

EA: When it comes to Sweden, the expectations of the state to be responsive and take a particular type of responsibility for its population are clear in the reactions from the international community; these seldom include an analysis of how the Swedish Folkhem has changed since the 1970s, given the marketization and deregulation of former centralized areas of welfare. The political discussions within the country often involve conservatives and right-wing politicians, who have been a force in the marketization of health and elderly care, and who are now pointing their fingers at the social democrats in government as those responsible for the failures of the current welfare system. In such critiques, there are often references to the historical baggage of the Swedish brand of social democracy.

\section{So if we should summarize our thoughts...}

Extraordinary times seem to bring with them a heightened attentiveness to the role of the state in protecting its citizens. In such times, it is, some scholars argue, important not to lose sight of the everydayness of state governance over life and death, of the stratifying effects of biopolitics in ordinary times (Brown 2020, Hartman 2020, Weizman 2020). As Saidiya Hartman (2020) writes, regarding the racist systems and the constant state of emergency they create: "The calculus involved in the social distribution of death and the making and policing of the divide between valued and disposable lives defines the very meaning of racial capitalism; premature death and gratuitous violence make life an aspiration and impossibility."

We know for certain - the reports and statistics are clear on this point - that the risks of contracting Covid-19 are unevenly distributed, and stratified along already existing structures of power, both globally and within regions and nations. Those portions of the population that are dependent on the care of others, socially and economically precarious and unable to self-quarantine and work from home, are those made most vulnerable to contamination; this is a general tendency both in countries that have a well-developed welfare system with relatively equal opportunities to access health care, and in those lacking such support systems. This tension between state protection and state neglect and the necropolitical effects of biopolitics are at the core of the question of reproduction and the future of the nation-state.

As Mbembe states, "some bodies are kept alive but in a state of injury" (Mbembe 2003: 21). A presupposition for lives that matter is grievability, and it is clear that bodies that do not conform to hegemonic norms can become ungrievable (Butler 2009: 14), or only grievable in a symbolic sense, after their departure, as politicized victims of neglect. For large parts of the population in Nicaragua, and for specific groups of the population in Sweden, there has never been a so-called 'normal existence', and therefore there will never be a return to a normal existence for all.

\section{Author biographies}

Linda Berg is Associate Professor of Gender Studies, Umeå Centre for Gender Studies, Umeå University, previous research has an emphasis on postcolonial- and feminist theorizing of political mobilizing, solidarity and transnational movements (including feminist and lgbti-activism in Central America).

Erika Alm is Associate Professor of Gender Studies, Department of Cultural Sciences, University of Gothenburg; their research interests include trans and intersex studies, gender non-conforming activism, biopolitics, and the governing of and knowledge production on sex, gender and sexuality.

\section{References}

Ahmed, Sara (2014). Cultural Politics of Emotions. Edinburgh: Edinburg University Press.

Al-Jazeera (2020). Nicaragua's 'express burials' hide true COVID-19 scale: Doctors. 19 May 2020. https://www.aljazeera.com/news/2020/5/19/nicaraguas-express-burials-hide-true-covid-19-scale-doctors Accessed 17 December 2021

Al-Jazeera (2021). Nicaragua's Ortega set to win another term after 'farce' election. 8 November 2021. https:// www.aljazeera.com/news/2021/11/8/early-results-show-ortega-win-in-controversial-nicaragua-poll Accessed 22 November 2021

AL PUEBLO DE NICARAGUA Y AL MUNDO INFORME SOBRE EL COVID-19 Y UNA ESTRATEGIA SINGULAR - LIBRO BLANCO - Mayo del 2020 de la Secretaría Privada de la Políticas Nacionales, Presidencia de la República.

Alm, Erika. (2021). A State Affair?: Notions of the State in Discourses on Trans Rights in Sweden. In: Alm, Erika et al (eds) Pluralistic Struggles in Gender, Sexuality and Coloniality: Challenging Swedish Exceptionalism. London: Palgrave Macmillan. 
Alm, Erika \& Berg, Linda (forthcoming). Parenting the Nation. State violence and reproduction in Nicaragua and Sweden. In: Kolankiewicz, Marta et al (eds) Struggles for Reproductive Justice in the era of Anti-genderism and Religious Fundamentalism. London: Palgrave Macmilllan.

Andrews, Kehinde (2020). The Other Pandemic. In: Evans, Brad (ed) The Quarantine Files: Thinkers in Self-Isolation. Los Angeles: Los Angeles Review of Books.

Anderberg, Johan (2021). Flocken: berättelsen om hur Sverige valde väg under pandemin. Malmö: MTM.

Asp, Viktoria et. al. (2015). Bara skog som brinner? : Utvärdering av krishanteringen under skogsbranden $i$ Västmanland 2014. Stockholm: CRISMART Försvarshögskolan.

Baltodano Isela (2020). Daniel Ortega: "No se ha dejado de trabajar, porque si se deja de trabajar el país se muere". $L a$ Prensa. https://www.laprensani.com/2020/04/15/politica/2662221-daniel-ortega-reaparece-publicamente Accessed 30 May 2021

Beauchamp, Toby (2019). Going stealth: transgender politics and U.S. surveillance practices. Durham: Duke University Press.

Bergh, Andreas, Erlingsson, Gissur (2009). Liberalization without Retrenchment: Understanding the Consensus on Swedish Welfare State Reforms. Scandinavian Political Studies 32(1), 71-93. https://doi.org/10.1111/j.1467-9477.2008.00210.x

Bradshaw, Sarah et al. (2008). Talking Rights or What Is Right? Understandings and Strategies around Sexual, Reproductive and Abortion Rights in Nicaragua. In: Mukhopadhyay, Maitrayee et al (eds) Gender, Society, and Development: A Global Sourcebook. Amsterdam: Royal Tropical Institute.

Brown, Wendy (2020). From Exposure to Manifestation. In: Evans, Brad (ed) The Quarantine Files: Thinkers in SelfIsolation. Los Angeles: Los Angeles Review of Books.

Butler, Judith (2009). Frames of War: When is Life Grievable? London: Verso.

Carlsson, Marcus (2020). Folkhälsomyndigheten har misslyckats - nu måste politikerna gripa in. Dagens Nyheter 14 April 2020. https://www.dn.se/debatt/folkhalsomyndigheten-har-misslyckats-nu-maste-politikerna-gripa-in/ Accessed January 122022

Celedón Lacayo, Alfredo J. et al (2020). Segundo pronunciamiento de profesionales de la salud independientes sobre la situación actual del COVID-19 en Nicaragua (open letter). 2020-05-18, published on website 2020-05-28. https://alianza-progresista.info/2020/05/28/segundo-pronunciamiento-de-profesionales-de-la-salud-independientes-sobre-la-situacion-actual-del-covid-19-en-nicaragua/ Accessed January 122022

Cisney, Vernon W. \& Morar, Nicolae (2015). Biopower: Foucault and Beyond. Chicago: University of Chicago Press.

Cruz-Feliciano, Héctor (2019). The Perils of Reconciliation: Achievements and Challenges of Daniel Ortega and the Modern FSLN. Latinamerican Perspective 46(1), 247-262. https://doi.org/10.1177/0094582X18803876

Enloe, Cynthia (2020). Pulling my COVID-19 language out of the trenches. In: Evans, Brad (ed) The Quarantine Files: Thinkers in Self-Isolation. Los Angeles: Los Angeles Review of Books.

Foucault, Michel (1978). The History of Sexuality: An introduction vol. 1. New York: Random House.

Franzoni, Juliana et al (2010) The Political and Social Economy of Care in Nicaragua: Familialism of Care under an Exclusionary Social Policy Regime. Gender and Development Program.
Fritzell, Johan (2016). Fattigdom, inkomst och jämlik hälsa: underlagsrapport till Kommissionen för jämlik hälsa. Stockholm: Kommissionen för jämlik hälsa.

Goodman, Peter (2020). Sweden Has Become the World's Cautionary Tale. New York Times 7 July 2020. https:// www.nytimes.com/2020/07/07/business/sweden-economy-coronavirus.html Accessed January 122022

Hallengren, Lena (2020). 'Svar på fråga 2019/20:1963 av Markus Wiechel (SD). Flockimmunitet'. Riksdagen 31 August 2020. https://www.riksdagen.se/sv/dokument-lagar/dokument/skriftlig-fraga/flockimmunitet_H7111963 Accessed January 122022

Haritaworn, Jin et al (2014). Queer necropolitics. London: Routledge.

Hartman, Saidiya (2020). The Death Toll. In: Evans, Brad (ed) The Quarantine Files: Thinkers in Self-Isolation. Los Angeles: Los Angeles Review of Books.

Heumann, Silke (2014). The Challenge of Inclusive Identities and Solidarities: Discourses on Gender and Sexuality in the Nicaraguan Women's Movement and the Legacy of Sandinismo. Bulletin of Latin American Research 33(3), 334-349. https://doi.org/10.1111/ blar. 12103

Huete-Pérez, Jorge A. et al (2021). First report on prevalence of SARS-CoV-2 infection among health-care workers in Nicaragua. PLoS ONE 16(1) https://doi.org/10.1371/journal.pone. 0246084

Jansson, Anders (2020). Jag anklagar er för att tysta coronadebatten. Aftonbladet 21 April 2020. https://www.aftonbladet. se/debatt/a/kJr5b6/jag-anklagar-er-for-att-tysta-coronadebatten Accessed January 122022

Kowalchuk, Lisa (2018). Patriarchy, New Left PostNeoliberalism, and the Valuing of Care Work: The Labor Conditions of Nicaraguan Nurses under Sandinismo's "Second Stage". Latin American Research Review 53(4), 741-756. http://doi.org/10.25222/larr.401

Lindbom, Anders (2001). Dismantling the Social Democratic Welfare Model? Has the Swedish Welfare State Lost Its Defining Characteristics?. Scandinavian Political Studies 24(3), 171-193. https://doi.org/10.1111/1467-9477.00052

Mbembe, Achille (2003). Necropolitics. Public Culture 15 (1), 11-40.

Mbembe, Achille (2019). Necropolitics. Durham: Duke University Press.

Miranda, Walfredo \& Salazar, Maynor (2021). Así se oculta la muerte por la COVID-19 en Nicaragua. Divergente 7 January 2021. https://www.divergentes.com/asi-enganaron-a-las-victimas-de-covid-19-y-sus-familiares-en-nicaragua/ Accessed 22 November 2021

OECD (2017). OECD Economic Surveys: Sweden 2017. OECD Publishing, Paris. https://www.oecd.org/economy/ surveys/Sweden-2017-OECD-economic-survey-overview. pdf Accessed January 122022

OECD (2019). OECD Economic Surveys: Sweden 2019. OECD Publishing, Paris. https://www.oecd-ilibrary.org/ economics/oecd-economic-surveys-sweden-2019_ c510039b-en Accessed January 122022

Orange, Richard (2020). The mood darkens in Sweden as high death rate raises tough questions over lack of lockdown. The Telegraph 8 June 2020. https://www.telegraph. co.uk/news/2020/06/08/mood-darkens-sweden-pm-lofven-criticised-severely-political/ Accessed January 12 2022 
Palm, Erik (2020). Swedish exceptionalism has been ended by coronavirus. The Guardian 26 June 2020 https://www. theguardian.com/commentisfree/2020/jun/26/ swedish-exceptionalism-coronavirus-covid19-death-toll Accessed January 122022

Pearson, Andy A. et al (2020). Nicaragua's surprising response to COVID-19. Journal Global Health 10(1). doi: 10.7189/ jogh.10.010371

Riksdagsdebatt (2021). Protokoll 2020/21:61. Riksdagen 8 January 2021.

Riksrevisionen (2008). Pandemier - hantering av hot mot människors hälsa (RiR 2008:1). Stockholm: Riksdagstryckeriet. https://www.riksrevisionen.se/rapporter/granskningsrapporter/2008/pandemier---hantering-av-hot-mot-manniskors-halsa.html Accessed January 122022

Salazar Mather, Thais et al (2020). Love in the time of COVID19: negligence in the Nicaraguan response. The Lancet Global Health 8(6). DOI: 10.1016/S2214-109X(20)30131-5

Solomon, Daina (2021). Nicaragua's Ortega set to win an election that the U.S. blast as 'pantomime'. Reuters 7 November 2021. https://www.reuters.com/world/americas/ nicaraguas-ortega-seeks-re-election-with-opposition-candidates-jail-2021-11-07/ Accessed 22 November 2021

Spade, Dean (2011). Normal life: administrative violence, critical trans politics, and the limits of law. Brooklyn, NY: South End Press.
Svensson, Olof (2021). Ebba Busch till nytt 'med berått mod'-angrepp. Aftonbladet 13 January 2021. https://www. aftonbladet.se/nyheter/a/EpJVoj/ebba-busch-till-nyttmed-beratt-mod-angrepp Accessed January 122022

The Local (2021). Swedish PM Stefan Löfven: Herd immunity 'never ever' part of coronavirus strategy. 26 April 2021. https://www.thelocal.se/20210426/today-swedish-pm-stefan-lofven-to-face-questions-over-coronavirus-strategy/ Accessed January 122022

Transgender Europe (2017). Overdiagnosed but underserved. Trans health care in Georgia, Poland, Serbia, Spain and Sweden. https://tgeu.org/healthcare/.

UN News (2020). "Nicaragua: After two years of crisis, more than 100,000 have fled the country". 10 March 2020. https://news.un.org/en/story/2020/03/1059051 Accessed 22 November 2021

Vänsterpartiet (2020). "Vill se förbättring av äldrevården, inte enbart utredning av covid-19 pandemin". 15 September 2020. https://sll.vansterpartiet.se/2020/09/15/v-vill-se-forbattring-av-aldrevarden-inte-enbart-utredning-av-covid19-pandemin/ Accessed January 122022

Weizman, Eyal (2020). Surveilling the Virus. In: Evans, Brad (ed) The Quarantine Files: Thinkers in Self-Isolation. Los Angeles: Los Angeles Review of Books.

Endnote: translations from Spanish to English, and Swedish to English by authors.

How to cite this article: Linda Berg \& Erika Alm. 2021. Conversation about the state in pandemic times: Necropolitics and the legacy of social democracy in Sweden and Nicaragua. Kulturella Perspektiv, vol. 30. Tema: Pandemi, s. 1-9

Mottagen: 9 augusti 2021 Accepterad: 14 januari 2022 Publicerad: 17 February 2022

Copyright: @ 2021.Författaren/författarna. Detta är en Open Access-artikel som distribueras enligt Creative Commons, licens CC-BY 4.0, som tillåter obegränsad användning, distribution och reproduktion i samtliga medieformat, förutsatt att ursprunglig(a) författare och källa uppges. Se http://creativecommons.org/licenses/by/4.0/. 